\title{
Pengaruh Penyuluhan dan Pelatihan tentang 3M-Plus terhadap Pengetahuan Pencegahan Penularan Covid-19
}

\author{
${ }^{1}$ Siti Thomas Zulaikhah*, ${ }^{2}$ Joko Wahyu Wibowo \\ 1Departemen IImu Kesehatan Masyarakat, Universitas Islam Sultan Agung, Semarang, \\ Indonesia \\ 2Departemen Gizi, Universitas Islam Sultan Agung, Semarang, Indonesia \\ ${ }^{*}$ Corresponding Author: \\ Jl. Raya Kaligawe KM 4 Semarang, Telp: 6583584; Fax: 6582455 \\ E-mail: sitithomas@unissula.ac.id \\ Received: \\ 15 Desember 2021 \\ Revised:
19 Desember 2021

\section{Accepted:} \\ 1 Januari 2022 \\ Published: \\ 15 Januari 2022
}

\begin{abstract}
Abstrak
Covid-19 merupakan penyakit yang tingkat penularannya cukup tinggi, sehingga perlu dilakukan upaya perlindungan kesehatan masyarakat yang dilakukan secara komprehensif. Tujuan kegiatan pengabdian masyarakat ini untuk mengetahui pengaruh penyuluhan dan pelatihan tentang 3M-Plus terhadap pengetahuan pencegahan penularan Covid-19 pada kader kesehatan di desa Gaji Guntur Demak. Desain pra eksperimen dengan rancangan perlakuan ulang (one group pre and postest design) yaitu dengan memberikan penyuluhan, talkshow dan pelatihan $3 \mathrm{M}$, yaitu menggunakan masker, mencuci tangan, menjaga jarak, sedang PLUS nya yaitu jaga hati, jaga gizi dan jaga kondisi. Peserta adalah kader kesehatan desa Gaji Guntur Demak yang berjumlah 23. Peserta diberikan pretes dan postes pada akhir kegiatan sebagai evaluasi terhadap kegiatan yang dilaksanakan. Skor pengetahuan sebelum dan sesudah kegiatan dibandingkan. Data yang terkumpul dianalisis menggunakan t-paired test. Rerata skor pengetahuan sebelum kegiatan adalah 26,35 dan sesudah kegiatan 27,52 , hasil analisis diperoleh nilai $p=0,002$. Penyuluhan dan pelatihan $3 \mathrm{M}$-Plus berpengaruh terhadap pengetahuan pencegahan penularan Covid-19.
\end{abstract}

Kata Kunci: Pencegahan Covid-19; 3M-Plus

\begin{abstract}
Covid-19 is a disease with a fairly high transmission rate, so it is necessary to carry out comprehensive public health protection efforts. The purpose of this community service activity is to determine the effect of education and training on 3M-Plus on knowledge of prevention of transmission. Covid-19 on health cadres in Gaji Guntur Village, Demak. Pre-experimental design with one group pre and posttest design, namely by counseling, talk shows and $3 \mathrm{M}$ training, using masks, washing hands, keeping distance, while the PLUS is taking care of the heart, taking care of nutrition and taking care of the condition. Participants are health cadres from Gaji Guntur Demak village, total 23 participants are given a pretest and posttest at the end of the activity as an evaluation of the activities carried out. Knowledge scores before and after the activity were compared. The collected data were analyzed using the t-paired test. The mean score of knowledge before the activity was 26.35 and after the activity was 27.52, the results of the analysis obtained $p$ value $=0.002$. Education and training $3 M$ Plus has an effect on knowledge of preventing the transmission of Covid-19.
\end{abstract}

Keywords: Covid-19 prevention; 3M Plus 


\section{PENDAHULUAN}

Covid-19 merupakan penyakit yang tingkat penularannya cukup tinggi, sehingga perlu dilakukan upaya perlindungan kesehatan masyarakat yang dilakukan secara komprehensif. Masyarakat memiliki peran penting dalam memutus mata rantai penularan Covid-19 agar tidak menimbulkan sumber penularan baru. Penularan Covid19 terjadi melalui droplet yang mengandung virus SARS CoV-2 yang masuk ke dalam tubuh melalui hidung, mulut dan mata.

Covid-19 ditularkan melalui kontak dekat dan droplet, bukan melalui transmisi udara. Orang-orang yang paling berisiko terinfeksi adalah mereka yang berhubungan dekat dengan pasien Covid-19 atau yang merawat pasien Covid-19. Tindakan pencegahan dan mitigasi merupakan kunci penerapan di pelayanan kesehatan dan masyarakat.Mengingat cara penularannya berdasarkan droplet infection dari individu ke individu, maka penularan dapat terjadi baik di rumah, perjalanan, tempat kerja, tempat ibadah, tempat wisata maupun tempat lain dimana terdapat orang berinteaksi social Penyebaran juga dapat terjadi melalui fomit di lingkungan langsung orang yang terinfeksi, karena itu, penyebaran virus COVID-19 dapat terjadi secara langsung melalui kontak dengan orang yang terinfeksi atau secara tidak langsung melalui kontak dengan permukaan lingkungan langsung atau benda-benda yang digunakan untuk atau oleh orang yang terinfeksi (misalnya, stetoskop atau termometer) (Cheng et al, 2019; Ong et al, 2020).

Tingkat menularnya (transmissibility) virus ini bergantung pada jumlah virus hidup yang diluruhkan oleh seseorang, terlepas dari apakah orang tersebut batuk dan mengeluarkan droplet atau tidak, jenis kontak yang terjadi dengan orang lain, dan langkah-langkah PPI yang dijalankan (WHO, 2020). Gejala yang ditunjukan oleh penderita Covid-19 dari hasil penelitian terhadap 51 penderita adalah demam (96\%), batuk $(47 \%)$, nyeri otot dan kelelahan $(31 \%)$, nyeri kepala $(16 \%)$, sesak dan nyeri dada $(14 \%)$, diare $(10 \%)$, dan nyeri tenggorokan $(6 \%)$, serta mual muntah $(6 \%)$ (Song et al., 2020) Perlindungan kesehatan masyarakat bertujuan mencegah terjadinya penularan dalam skala luas yang dapat menimbulkan beban besar terhadap fasyankes. Tingkat penularan COVID-19 di masyarakat dipengaruhi oleh adanya pergerakan orang, interaksi antar manusia dan berkumpulnya banyak orang, untuk itu perlindungan kesehatan masyarakat harus dilakukan oleh semua unsur yang ada di masyarakat baik pemerintah, dunia usaha, aparat penegak hukum serta komponen masyarakat lainnya Tujuan pengabdian masyarakat ini untuk mengetahui pengaruh penyuluhan dan pelatihan tentang 3M-Plus terhadap pengetahuan pencegahan penularan Covid-19 pada kader kesehatan di desa Gaji Guntur Demak.

\section{METODE}

Metode kegiatan pengabdian masyarakat yang digunakan pra-eksperimen dengan rancangan perlakuan ulang (one group pre and postest design) yaitu memberikan penyuluhan, talkshow dan pelatihan $3 \mathrm{M}$, meliputi praktik menggunakan masker yang benar, praktik mencuci tangan yang benar, menjaga jarak, sedang PLUS nya adalah upaya untuk meningkatkan imunitas tubuh yaitu jaga hati, jaga gizi dan jaga kondisi. Jaga hati adalah bagaimana supaya kita tidak menyikapi pandemi Covid-19 ini dengan rasa takut, panik, cemas, tegang, atau stres yang berkepanjangan, sedang jaga gizi adalah bagaimana supaya kita tidak terlambat makan, makan dengan gizi seimbang, dan jaga kondisi adalah bagiamana supaya kita dapat beristirahat yang cukup, berolahraga, berjemur, memanfaatkan waktu dengan berkebun, bertaman, dan sebaiangya. 
Peserta adalah kader kesehatan desa Gaji Guntur Demak yang berjumlah 23. Pelaksanaan kegiatan dengan protokol kesehatan yaitu peserta wajib menggunakan masker, saat datang di lokasi kegiatan dikur suhu tubuhnya, diminta cuci tangan, jarak tempat duduk 1-2 $\mathrm{m}$, ruangan luas dan terbuka serta waktu pelaksanaan dibatasi maksimum 2 jam. Peserta diberikan pretes pada awal kegiatan dan postes pada akhir kegiatan sebagai evaluasi terhadap kegiatan yang dilaksanakan. Materi pretes dan postes adalah pengetahuan tentang pencegahan penularan Covid-19 dengan 3M-Plus yang terdiri dari 30 item pertanyaan, dimana jawaban benar mendapat skor 1 dan salah 0 . Skor pengetahuan sebelum dan sesudah kegiatan dibandingkan. Data yang terkumpul diuji normalitas dengan Shapiro wilks dan dianalisis menggunakan $t$-paired test karena distribusi data normal (Dahlan, 2014).

Tahap pelaksanaan kegiatan:

a. Peserta diminta berkumpul di Balai desa Gaji dengan mematuhi protokol kesehatan, menggunakan masker, diminta cuci tangan dan diukur suhu tubuhnya.

b. Peserta diberi lembar kuesioner pengetahuan tentang pencegahan penularan Covid-19 dengan 3M-PLUS, sebelum peserta mengisi kita jelaskan dulu bagaimana cara mengisi kuesioner, hasil jawaban peserta ini kita beri skor dan kita catat sebagai hasil pretes.

c. Peserta mendapatkan penyuluhan, talkshow dan pelatihan tentang pencegahan penularan Covid-19 dengan 3M-PLUS, dibantu media media LCD dan vidio serta tanya jawab sekitar 1 jam.

d. Peserta mengikuti praktik cuci tangan yang benar dengan 6 langkah yang dipimpin oleh instruktur.

e. Peserta mengikuti talkshow tentang bagaimana menggunakan masker yang benar, bagaimana jika harus melepas pada saat makan, berapa jam maksimum digunakan untuk satu masker dan lain-lain

f. Peserta mendengarkan penyuluhan tentang jaga gizi, yang disampaikan oleh doktor ahli di bidang Gizi, yaitu Dr. dr. Joko Wahyu W, Mkes

g. Peserta mendengarkan penyuluhan tentang $3 \mathrm{M}$, jaga hati dan jaga kondisi, yang disampaikan oleh doktor ahli di bidang Kesehatan Masyarakat yaitu Dr. Siti Thomas Z, SKM.MKes

h. Peserta diberi lembar kuesioner pengetahuan tentang pencegahan penularan Covid-19 dengan 3M-PLUS, peserta diminta mengisi, hasil jawaban peserta kita beri skor dan kita catat sebagai hasil postes.
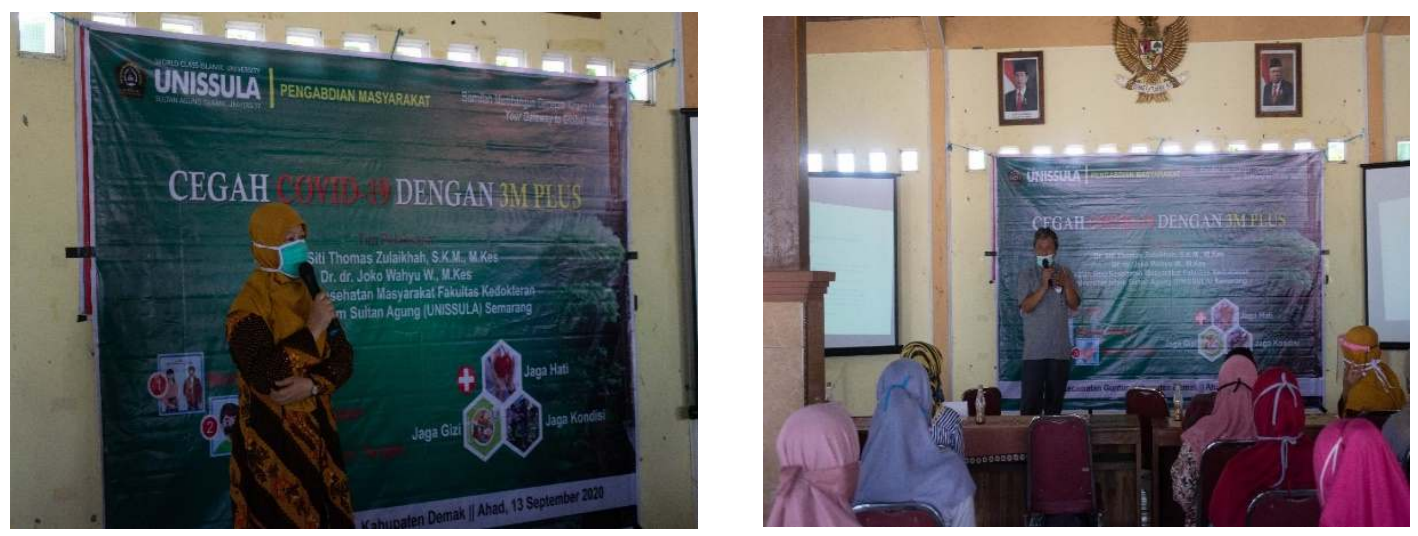

Gambar 1. Penyuluhan tentang tentang pencegahan penularan Covid-19 dengan 3M-PLUS 3M PLUS 

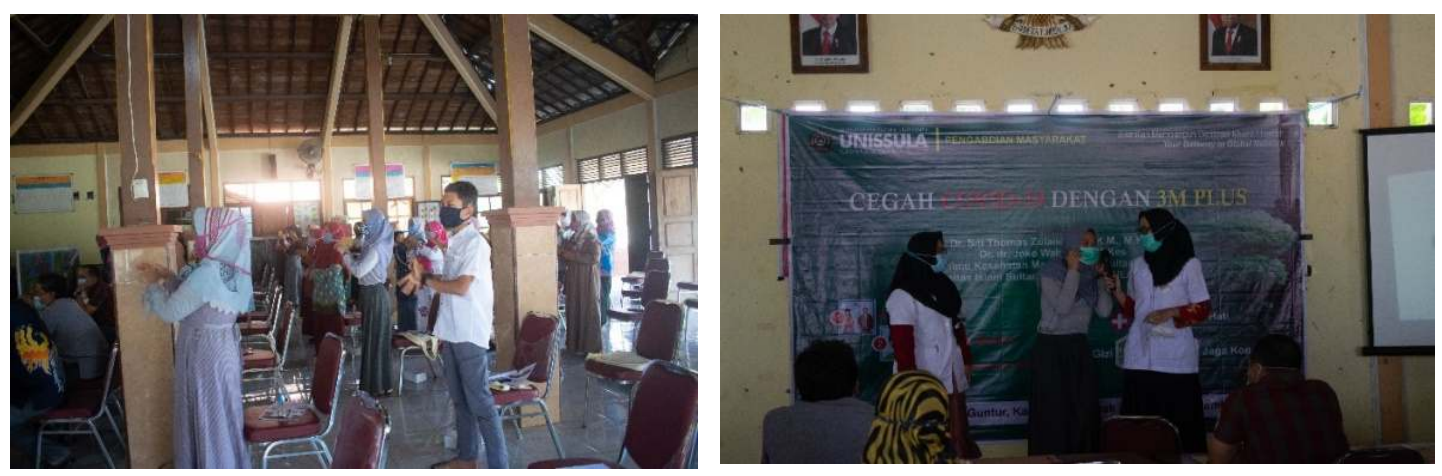

Gambar 2. Pelatihan tentang cuci tangan dan Talk Show

\section{HASIL DAN PEMBAHASAN}

Kegiatan pengabdian masyarakat ini dilaksanakan di Desa Gaji Kecamatan Guntur Kabupaten Demak, desa ini mempunyai luas $306.086 \mathrm{Ha}$, dengan batas wilayah:
- Utara
: Desa Krandon, Temuroso, Kecamatan Sayung
- Timur
: Desa Sidokumpul, Temuroso, Kecamatan Tegowanu
- Selatan
: Desa Sidokumpul, Blerong, Kecamatan Mranggen
- Barat
: Desa Blerong, Kecamatan Sayung

Tabel 1. Deskripsi Item Pertanyaan Pengetahuan Tentang Pencegahan Penularan Covid-19 (3M-Plus)

\begin{tabular}{|c|c|c|c|c|c|c|c|c|c|}
\hline \multirow{3}{*}{ No } & \multirow{3}{*}{ Item Pertanyaan } & \multicolumn{4}{|c|}{ Pre Test } & \multicolumn{4}{|c|}{ Pos Test } \\
\hline & & \multicolumn{2}{|c|}{$\begin{array}{l}\text { Jumlah } \\
\text { Menjawab } \\
\text { Benar }\end{array}$} & \multicolumn{2}{|c|}{$\begin{array}{c}\text { Jumlah } \\
\text { Menjawab Salah }\end{array}$} & \multicolumn{2}{|c|}{$\begin{array}{l}\text { Jumlah } \\
\text { Menjawab } \\
\text { Benar }\end{array}$} & \multicolumn{2}{|c|}{$\begin{array}{c}\text { Jumlah } \\
\text { Menjawab Salah }\end{array}$} \\
\hline & & $\begin{array}{c}\mathrm{n} \\
\text { (orang) }\end{array}$ & $\%$ & $\begin{array}{c}n \\
\text { (orang) }\end{array}$ & $\%$ & $\begin{array}{c}n \\
\text { (orang) }\end{array}$ & $\%$ & $\begin{array}{c}n \\
\text { (orang) }\end{array}$ & $\%$ \\
\hline 1. & $\begin{array}{l}\text { Berapa langkah } \\
\text { dalam cuci tangan } \\
\text { menurut WHO? }\end{array}$ & 17 & $74 \%$ & 6 & $26 \%$ & 20 & $87 \%$ & 3 & $13 \%$ \\
\hline 2. & $\begin{array}{l}\text { Berapa lama cuci } \\
\text { tangan } \\
\text { menggunakan } \\
\text { sabun yang sudah } \\
\text { ditentukan WHO? }\end{array}$ & 9 & $39 \%$ & 14 & $61 \%$ & 12 & $52 \%$ & 11 & $48 \%$ \\
\hline 3. & $\begin{array}{l}\text { Perilaku Hidup } \\
\text { Bersih dan Sehat } \\
\text { perlu dilakukan } \\
\text { oleh masyarakat } \\
\text { untuk } \\
\text { mengantisipasi } \\
\text { penyebaran } \\
\text { COVID-19. } \\
\text { Dibawah ini adalah } \\
\text { contoh-contohnya }\end{array}$ & 22 & $96 \%$ & 1 & $4 \%$ & 22 & $96 \%$ & 1 & $4 \%$ \\
\hline
\end{tabular}


4. Cuci tangan yang

paling baik dilakukan dengan menggunakan $\begin{array}{llllllll}23 & 100 \% & 0 & 0 \% & 23 & 100 \% & 0 & 0 \%\end{array}$ sabun pada..

\begin{tabular}{|c|c|c|c|c|c|c|c|c|c|}
\hline 5. & $\begin{array}{l}\text { Perhatikan } \\
\text { langkah-langkah } \\
\text { cara mencuci } \\
\text { tangan berikut ini! }\end{array}$ & 15 & $65 \%$ & 8 & $35 \%$ & 17 & $74 \%$ & 6 & $26 \%$ \\
\hline 6. & $\begin{array}{l}\text { Berapa lama waktu } \\
\text { penggunaan } \\
\text { masker kain? }\end{array}$ & 22 & $96 \%$ & 1 & $4 \%$ & 21 & $91 \%$ & 2 & $9 \%$ \\
\hline 7. & $\begin{array}{l}\text { Berapa lapis } \\
\text { masker kain yng } \\
\text { direkomendasikan } \\
\text { oleh WHO? }\end{array}$ & 7 & $30 \%$ & 16 & $70 \%$ & 18 & $78 \%$ & 5 & $22 \%$ \\
\hline 8. & $\begin{array}{l}\text { Bagaimana cara } \\
\text { mencuci masker } \\
\text { kain yang benar } \\
\text { setelah dipakai? }\end{array}$ & 21 & $91 \%$ & 2 & $9 \%$ & 20 & $87 \%$ & 3 & $13 \%$ \\
\hline 9. & $\begin{array}{l}\text { Siapa saja yang } \\
\text { dianjurkan } \\
\text { memakai masker? }\end{array}$ & 23 & $100 \%$ & 0 & $0 \%$ & 23 & $100 \%$ & 0 & $0 \%$ \\
\hline 10. & $\begin{array}{l}\text { Bagaimana cara } \\
\text { menggunakan } \\
\text { masker yang } \\
\text { benar? }\end{array}$ & 15 & $65 \%$ & 8 & $35 \%$ & 21 & $91 \%$ & 2 & $9 \%$ \\
\hline 11. & $\begin{array}{l}\text { Bagaimana cara } \\
\text { berkomunikasi } \\
\text { selama masa } \\
\text { pandemi? }\end{array}$ & 15 & $65 \%$ & 8 & $35 \%$ & 16 & $70 \%$ & 7 & $30 \%$ \\
\hline 12. & $\begin{array}{l}\text { Berapa jarak } \\
\text { minimal untuk jaga } \\
\text { jarak? }\end{array}$ & 23 & $100 \%$ & 0 & $0 \%$ & 23 & $100 \%$ & 0 & $0 \%$ \\
\hline 13. & $\begin{array}{l}\text { Apa pentingnya } \\
\text { menjaga jarak } \\
\text { pada kondisi saat } \\
\text { ini? }\end{array}$ & 23 & $100 \%$ & 0 & $0 \%$ & 22 & $96 \%$ & 1 & $4 \%$ \\
\hline 14. & $\begin{array}{l}\text { Cara social } \\
\text { distancing/ } \\
\text { physical distancing } \\
\text { yang aman yaitu }\end{array}$ & 18 & $78 \%$ & 5 & $22 \%$ & 19 & $83 \%$ & 4 & $17 \%$ \\
\hline 15. & $\begin{array}{l}\text { Orang yang paling } \\
\text { berpotensi terkena } \\
\text { COVID-19 adalah }\end{array}$ & 21 & $91 \%$ & 2 & $9 \%$ & 20 & $87 \%$ & 3 & $13 \%$ \\
\hline 16. & $\begin{array}{l}\text { Makanan apa yang } \\
\text { ibu ketahui untuk } \\
\text { meningkatkan } \\
\text { kekebalan tubuh } \\
\text { selama masa } \\
\text { pandemi? }\end{array}$ & 23 & $100 \%$ & 0 & $0 \%$ & 23 & $100 \%$ & 0 & $0 \%$ \\
\hline
\end{tabular}


17. Apakah yang menjadi acuan

untuk mengkonsumsi $21 \quad 91 \%$ 2

$9 \%$

23

$100 \%$

saat masa

pendemi?

18. Bahan makanan

apa yang

mengandung

vitamin dan

mineral yang

15

$65 \%$

8

$35 \%$

18

$78 \%$

5

$22 \%$

meningkatkan

daya tahan tubuh

dimasa pandemi?

19. Bagaimana cara memasak sayur yang benar?

$\begin{array}{llllllll}22 & 96 \% & 1 & 4 \% & 21 & 91 \% & 2 & 9 \%\end{array}$

20. Apa bahan makanan yang harus dihindari pada masa pandemi?

21. Bagaimana cara menjaga kondisi pada masa $23 \quad 100 \%$ pandemi?

22. Berapa lama olahraga yang dianjurkan?

$\begin{array}{llllllll}23 & 100 \% & 0 & 0 \% & 23 & 100 \% & 0 & 0 \%\end{array}$

23. Berapa lama tidur yang disarankan?

$19 \quad 83 \%$
24. Bagaimana cara
untuk terhindar dari tertularnya

$18 \quad 78 \%$
penyakit corona?

25. Bagaimana sikap kita selama menghadapi masa $22 \quad 96 \%$

$23 \quad 100 \% \quad 0$

$5 \quad 22 \%$

$0 \%$ 23

3

$100 \%$

$0 \%$ pandemi?

26. Apa yang harus dilakukan untuk menjaga hati dalam masa pandemic

27. Bagaimana sikap kita pada orang yang terkena penyakit covid?

\begin{tabular}{|c|c|c|c|c|c|c|c|c|}
\hline $\begin{array}{l}\text { menjaga hati } \\
\text { dalam masa } \\
\text { pandemic }\end{array}$ & 23 & $100 \%$ & 0 & $0 \%$ & 23 & $100 \%$ & 0 & $0 \%$ \\
\hline $\begin{array}{l}\text { Bagaimana sikap } \\
\text { kita pada orang } \\
\text { yang terkena } \\
\text { penyakit covid? }\end{array}$ & 23 & $100 \%$ & 0 & $0 \%$ & 19 & $83 \%$ & 4 & $17 \%$ \\
\hline $\begin{array}{l}\text { Bagaimana sikap } \\
\text { kita selama } \\
\text { menghadapi masa } \\
\text { pandemi? }\end{array}$ & 22 & $96 \%$ & 1 & $4 \%$ & 20 & $87 \%$ & 3 & $13 \%$ \\
\hline
\end{tabular}




\begin{tabular}{|c|c|c|c|c|c|c|c|c|c|}
\hline 29. & $\begin{array}{l}\text { Bagaimana } \\
\text { menjaga perasaan } \\
\text { saat masa } \\
\text { pandemi? }\end{array}$ & 22 & $96 \%$ & 1 & $4 \%$ & 23 & $100 \%$ & 0 & $0 \%$ \\
\hline 30 & $\begin{array}{l}\text { Bagaimana } \\
\text { penerapan ibadah } \\
\text { saat masa } \\
\text { pandemi? }\end{array}$ & 23 & $100 \%$ & 0 & $0 \%$ & 23 & $100 \%$ & 0 & $0 \%$ \\
\hline
\end{tabular}

\section{KESIMPULAN}

Kegiatan pengabdian masyarakat melalui penyuluhan, talkshow dan pelatihan 3M-Plus ini berpengaruh terhadap pengetahuan pencegahan penularan Covid-19. Peserta juga dapat mempraktikkan menggunakan masker yang benar termasuk melepas masker pada saat makan, mencuci tangan menggunakan sabun dengan cara yang benar dan menjaga jarak (3M) serta PLUS yaitu jaga hati, jaga gizi, jaga kondisi supaya imunitas tubuh meningkat dan penularan Covid-19 dapat dicegah.

\section{UCAPAN TERIMA KASIH}

Tim Pengabdian Kepada Masyarakat dari Fakultas Kedokteran Universitas Islam Sultan Agung mengucapakan terima kasih kepada Kepala Desa Gaji, Kecamatan Guntur Kabupaten Demak beserta jajarannya serta Kepala Puskesmas Guntur II yang telah memberikan ijin guna terselenggaranya kegiatan "Penyuluhan Dan Pelatihan Tentang 3m-Plus Terhadap Pengetahuan Pencegahan Penularan Covid-19". Tim Pengabdian Kepada Masyarakat juga menyampaikan terimakasih kepada LPPM Unissula yang telah mendanai kegiatan ini.

\section{DAFTAR PUSTAKA}

Cheng, V. C., Wong, S. C., Chen, J. H., Yip, C. C., Chuang, V. W., Tsang, O. T., ... \& Yuen, K. $Y$. (2020). Escalating infection control response to the rapidly evolving epidemiology of the coronavirus disease 2019 (COVID-19) due to SARS-CoV-2 in Hong Kong. Infection Control \& Hospital Epidemiology, 41(5), 493-498.

Dahlan, M.S. (2014). Pintu Gerbang mamahami Statistik, Metodologi dan Epidemiologi. Sagung Seto

Quyumi, E., \& Alimansur, M. (2020). Upaya Pencegahan Dengan Kepatuhan Dalam Pencegahan Penularan Covid-19 Pada Relawan Covid. JPH Recode, 4(1), 81-87.

Yanti, N. P. E. D., Nugraha, I. M. A. D. P., Wisnawa, G. A., Agustina, N. P. D., \& Diantari, N. P. A. (2020). Gambaran pengetahuan masyarakat tentang covid-19 dan perilaku masyarakat di masa pandemi covid-19. Jurnal Keperawatan Jiwa, 8(3), 485-490.

Hadisaputro, S., Nizar, M., \& Suwandono, A. (2011). Epidemiologi manajerial. Semarang. Badan Penerbit UNDIP. Hal, 22.

Jaji. (2020). Pengaruh Pendidikan Kesehatan Dengan Media Leafletterhadap Pengetahuan Warga Dalam Pencegahan Penularan Covid 19 | Jaji | Proceeding Seminar Nasional Keperawatan. Semin Nas [Internet]. Available from: http://conference.unsri.ac.id/index.php/SNK/article/view/1764

Notoatmodjo S. (2012). Promosi Kesehatan dan Perilaku Kesehatan. Rineka Cipta 
Ong, S. W. X., Tan, Y. K., Chia, P. Y., Lee, T. H., Ng, O. T., Wong, M. S. Y., \& Marimuthu, K. (2020). Air, surface environmental, and personal protective equipment contamination by severe acute respiratory syndrome coronavirus 2 (SARS-CoV-2) from a symptomatic patient. Jama, 323(16), 1610-1612.

Priyono. (2014). Teori Sikap dan Perilaku dalam Kesehatan. Nuha Medica

Saputra A.W., \& Simbolon I. (2020). Hubungan Tingkat Pengetahuan Tentang Covid- Untuk Mengurangi Penyebaran Covid-19 Di Kalangan Mahasiswa Berasrama Universitas Advent Indonesia. J Keperawatan Univ Klabat. 4(2):1-7.

Song, F., Shi, N., Shan, F., Zhang, Z., Shen, J., Lu, H., ... \& Shi, Y. (2020). Emerging 2019 novel coronavirus (2019-nCoV) pneumonia. Radiology, 295(1), 210-217.

Tjan S. (2013). Hubungan Penyuluhan dengan Pengetahuan, Sikap, dan Perilaku Ibu Hamil tentang HIV dan Program Voluntary Counseling and Testing. eJournal Kedokt Indones. 1(2).

World Health Organization. (2020). Anjuran Mengenai Penggunaan Masker dalam Konteks COVID-19. Diakses di https://www.who.int/docs/defaultsource/searo/indonesia/covid19/anjuran-mengenai-penggunaan-masker-dalamkonteks-covid-19-june-20.pdf?sfvrsn=d1327a85 2, 16 September 2020.

Wu, Y. C., Chen, C. S., \& Chan, Y. J. (2020). The outbreak of COVID-19: An overview. Journal of the Chinese medical association, 83(3), 217. 